\title{
Sophie de Grouchy on the Cost of Domination in the Letters on Sympathy and Two Anonymous Articles in Le Républicain
}

\author{
Sandrine Berges*
}

\begin{abstract}
Political writings of eighteenth-century France have been so far mostly overlooked as a source of republican thought. Philosophers such as Condorcet actively promoted the ideal of republicanism in ways that can shed light on current debates. In this paper, I look at one particular source: Le Républicain, published in the summer 1791, focusing on previously unattributed articles by Condorcet's wife and collaborator, Sophie de Grouchy. Grouchy, a philosopher in her own right, is beginning to be known for her Letters on Sympathy, a response to Adam Smith's Theory of Moral Sentiment, which she published at the same time as her translation of that text into French. I argue, further, that in the texts, which I attribute to Grouchy, we can find the early development of a commercial republican theory, a belief, which is reflected in her discussion of the 'cost' of tyranny.
\end{abstract}

\section{INTRODUCTION}

Condorcet's political writings have recently been brought into focus with a new English edition, ${ }^{1}$ and the claim has been made that he defended a view of freedom as nondomination - this being a leading claim of neorepublicans - the view that to be free one must not be subject to arbitrary power, even when that power does not directly interfere with us. ${ }^{2}$ Although the essays in that volume do point to Condorcet holding such a view of freedom, I believe that this claim would be best served by studying the writings published in Condorcet's short-lived newspaper, Le Républicain. ${ }^{3}$ In this paper I propose to take the first steps in this project, focusing on the contributions of one of the authors of Le Républicain, Condorcet's wife and collaborator, Sophie de Grouchy. Grouchy, a philosopher in her own right, is beginning to be known for her Letters on Sympathy, a response to Adam Smith's Theory of Moral Sentiment which she published at the same time as her translation of that text into French. We know that she wrote more ${ }^{4}$-but we are not aware of any other texts published in her name. I will argue that some of the articles published in Le Républicain were either written or cowritten by Grouchy.

* Bilkent University.

(C) The Author 2015. Published by Oxford University Press on behalf of The Hegeler Institute.

All rights reserved. For permissions, please e-mail: journals.permissions@oup.com 
Sophie de Grouchy, an aristocrat who embraced atheism as she discovered Rousseau, became politically active after her marriage in 1786, setting up a salon in Condorcet's house at the Hotel des Monnaies, with international luminaries such as Jefferson and Paine among her guests. ${ }^{5}$ Her reputation, in royalist circles, was that of a fierce republican who unduly influenced her more reasonable husband. ${ }^{6}$ The texts I attribute to Grouchy here do show her to be a fairly radical republican. Their philosophical significance is owed not only to the fact that they help situate Le Républicain in the neorepublican tradition, but also because they contribute to providing a richer understanding of liberty as nondomination, one which has a moral as well as a political element.

\section{FRENCH REPUBLICANISM WITH AN ANGLO-AMERICAN TWIST: CONDORCET, GROUCHY, AND PAINE}

Condorcet started Le Républicain together with his wife, Sophie de Grouchy, their American friend Thomas Paine, Etienne Dumont (the Swiss translator of Bentham), and Jacques-Pierre Brissot and Achilles Duchastellet-both part of the political circle of the Girondins. The journal lasted for just over a month in the summer 1791. Its aim, stated in its opening article, "Avis aux Français," was to promote the ideal of republicanism - over the less radical proposals of constitutional monarchy-attempting: "to enlighten minds on the subject of republicanism, which is slandered because it is misunderstood." ${ }^{7}$ A theme that is strongly present throughout the articles of Le Républicain is that of the threat to freedom constituted by monarchy. It does not matter, says Paine, whether a monarch is "a fool, a hypocrite or a tyrant." What matters is that this individual has 'absolute power' over everyone, including those who are not yet born. ${ }^{8}$

This emphasis on the potential and arbitrary character of monarchical oppression puts the writers of Le Républicain squarely in the neorepublican tradition, i.e., that which emphasizes the idea that liberty is freedom from domination. To be free is not, in that sense, merely to be free of interference-as the subject of a benign monarch might be-but to be free of the potential interference of one who has absolute power over us and may choose to exert it at any point in time. The benign monarch will die, and his heir-who will rule over the next generation-may not be benign. And, as Paine and Condorcet both point out, a people who know that their children will not be free cannot call themselves free. ${ }^{9}$

The idea that a potential domination is a threat to liberty is also developed in Grouchy's Letters on Sympathy, a text that has all but disappeared from the recorded history of philosophy. ${ }^{10}$ In The Letters Grouchy shares Smith's view that sympathy is the source of our ability to form moral judgments, but her account differs from Smith's in two principal respects. First, she does not accept his postulate that sympathy is a given that needs no explanation, and instead she seeks to understand its physiological origins. Secondly, she is very much concerned to show the implications of a moral theory that has sympathy as a central element, not just for the development of humanity in general, as is Smith's concern, but for those attempting to create a republic. She is concerned with rebuilding human relations in a world where 
tyranny and arbitrary power may no longer be directly present but have left harmful traces in the form of laws, institutions, traditions, and attitudes of one class towards another.

There is a strong sense in which her Letters provide the ethical theory behind the sort of republicanism defended by herself, Condorcet, and Paine. They establish first, that domination is harmful as it prevents people from developing sympathy towards each other, and therefore from developing moral judgment. But they also argue that private property and free markets are not obstacles to nondomination, provided they do not lead to great inequalities (thus marking her allegiance to an Anglo-American form of commercial republicanism). In section four, I will go through these arguments as they are found in the Letters, but also in two of the articles from Le Républicain, and attempt to expose their philosophical depth and subtlety. First, I will attempt to establish that the texts of Le Républicain were indeed written, or cowritten by Grouchy.

\section{ATTRIBUTION OF THE TEXTS}

\subsection{Grouchy's involvement in Le Républicain}

Condorcet, Paine, Duchastellet, Dumont, and Brissot have all been named as editors of Le Républicain. ${ }^{11}$ But although Grouchy did write about her involvement (in correspondence with Dumont), she was never named as an editor and only referred to as a possible contributor in passing. ${ }^{12}$

The very first text published by Le Républicain was written by Paine and signed Duchastellet. As Paine wrote in English, the text had to be translated and this was (almost certainly) done by Grouchy. ${ }^{13}$ Thus Grouchy was involved from the first, in the positioning of the journal and its contributors as republicans, at a time when this was considered a dirty word and very few would claim it as their own. ${ }^{14}$

Grouchy's role in the production of the journal is also apparent from the circumstances of its demise. The decision to stop publishing was taken after the Champs de Mars incident at which Sophie was present with her daughter and during which the army, led by Lafayette, shot at the crowds, causing chaos and many deaths. Grouchy wrote to Dumont that "Brissot was forced to suspend the publication of Le Républicain because they could not bear to have any of its contributors locked up, even temporarily, and that people are being arrested, under any pretext relative to the Champs de Mars affair." 15 Condorcet was profoundly shocked by the fact that his wife and daughter had been present during the attack, and this may well have led him to seek any measure to protect them from further potential harm. ${ }^{16}$

There are some fairly convincing reasons for believing that Grouchy played a significant role in the production of Le Républicain. Further than that, I believe we can attribute to her the authorship of two articles: the "Letter from a young mechanic," and (as partial author) "Observations on the King's letter." In the following subsections, I will give a brief description of the two texts in question, while attempting to tease out some of what I regard as stylistic and historical evidence for Grouchy's authorship. In section three, I will focus on the content of those texts, and argue that they fit in with the republican ideology that we find in Grouchy's Letters on Sympathy. 


\section{2. "Letter from a Young Mechanic"}

This short text, published at the end of the third issue of the journal, on 16 July 1791, purports to be from a young mechanic, a student of Vaucauson, and an adept at making 'talking heads', and other automata. In the "Letter," he proposes a solution to the perceived dangers of republicanism, consisting in replacing the royal family and its entourage by well-designed automata who will behave in all manners like the real ones, with the automaton-king signing whatever documents are presented to it. The cost, the author goes on to say, though high, will be far cheaper than that of maintaining the actual royal family. But more importantly, the author concludes, the royal automata will never constitute a danger to liberty in the way that a real king does.

The reference to Vaucauson brings Condorcet to mind. Already Condorcet had sung the praises of the famous mechanic, citing his work as an example of the sort of technical activity that could be just as inspirational as theories. ${ }^{17}$ On the other hand, the style of the text is very unlike Condorcet's. A week before the publication of this third issue, and two days before that of the second, Condorcet had given a speech on republicanism 'De La République,' which was dry, a little boring, and though according to his friend Brissot, the speech appealed alternatively to reason and the heart, it did not appeal to the public's sense of humor. ${ }^{18}$ Grouchy, although also reputed for her seriousness, is not above the odd sarcasm at the expense of those she sees as the oppressors. In her Letters, she argues that hereditary rights offer 'presumptuous mediocrity' the means of elevation to tyrannical power. ${ }^{19}$ Whereas Condorcet tries to remain respectful, even when he is highly critical, his wife has no qualms about being sometimes downright insulting. And indeed, the "Letter from the Young Mechanic" is insulting: it reduces the function of the royal family to no more than a shiny display and a few symbolic gestures that an automated doll could fulfill just as well. Dumont's assessment of the husband and wife's character reflects this difference in styles: Condorcet, he tells us in his memoirs, had a 'reflective enthusiasm' and his wife an emotional one. We don't know to what extent this appreciation is due to the sort of prejudice that was rampant at the time, namely, that women are 'sensible' beings, that is, moved by their sentiments and sensations more than by reason. ${ }^{20} \mathrm{But}$ it may also simply be a comment on the fact that Condorcet was more cautious in expressing his republican sentiments - a fact that would exclude him as the author of that "Letter."

\section{3. "Observations on the King's Letter"}

This second text, in two parts, offers a series of comments on a letter penned by Louis XVI just before he attempted his escape from France. The letter itself, as shown by the various passages quoted in the article, complains at the unfair treatment the king has received from his subjects and enjoins them to return to a healthier and more virtuous state: that is, to love him. The author of the article argues vigorously against the king's various demands and recommendations, showing that a relationship that involves the subject loving the monarch is despotic and destructive of liberty. More particularly, the author looks at the King's defense of his 'civil list,' 
the large income paid to him through taxation, and the king's attack on the clubs, the discussion groups that were set up in the early days of the revolution. The article is probably one Dumont refers to in his memoirs. That is, it was drafted by Dumont, left by him at the Condorcet's after he left for England, then modified with additions of an antimonarchical character of which Dumont did not approve and printed in issues two and three of the journal. In Dumont's own words:

I had written a piece for that republican journal. It was published in the first two issues, but in my absence, after my departure and with alterations that were unfaithful. These alterations were additions and suppressions injurious towards the king which were not conform to either my opinions nor my character. $^{21}$

Although it is a long piece, given Dumont's comments on the nature of the modifications, it is not difficult to identify the passages that constituted unwelcome additions: one need simply to look for passages that could be construed as insulting to the King of France.

Two such passages bear the clear mark of Grouchy. In one, she discusses the claim that the love for their king is a virtue of the French. ${ }^{22}$ In response she describes the mechanisms of the growth and loss of such an emotion, in a way that is strongly reminiscent of the theory she outlines in the Letters on Sympathy. Letting go of their admiration for a king, she says, was a way for the French to grow up, to achieve emotional maturity, and to replace stupidity for noble sentiments. Unlike Smith, who thinks that we do have a natural affection for kings, Grouchy believes that this is at best a childish sentiment, a sort of vertigo at the thought of somebody falling from such great heights, but that we are otherwise predisposed to dislike the sort of inequality that places certain individuals so much higher than us. ${ }^{23}$

A second passage, a couple of pages later, describes the King's performance at the opening ceremony for the Etats Generaux. The text is no doubt more derogatory of the King's person than Dumont would have wanted. The King's appearance is said to have opened up the eyes of the nation, and helped shake the superstition that previously caused them to hold the King in esteem. The King's attitude is described as poised between "hatred and disdain." His "strange logic" is put down to the fact that "his head is crushed by a crown," and he is said to be but the toy of his brothers, his wife and ministers. The vehemence and lyricism of the insults, again, bring to mind Grouchy more than the sober Condorcet.

In the second half of the text, the author addresses the rights and wrongs of the civil list, the King's salary, a tax levied for the sake of keeping up the King's entourage - the King having claimed in his letter that services rendered him were services rendered to the state. The author explodes: "What! All these decorated valets and all these flattering and corrupting courtiers are beneficial to the state! We would owe them the same honours and tribute we do the warriors who fight for us and the philosophers who enlighten us!"24 This passage, it is clear, cannot have been written by either Dumont-it is too strongly antiroyalist-nor Condorcet, whose modesty would have prevented him from claiming honor for himself while at the 
same time making it clear that he was, indeed, one of the philosophers referred to in contrast to the courtiers. Both in style and in content this passage is again almost certainly Grouchy's.

\section{THE DISTINCTIVE CONTENT OF THE WORKS: THE COST OF DOMINATION}

The texts I have attempted to establish as the works (even if only as part-author) of Grouchy resemble, in their content, the defense of liberty as nondomination that she can be seen to offer in her Letters on Sympathy. That is, in both the letters and the articles she emphasizes that domination is harmful regardless of whether there is any actual interference. All that matters is the possibility of interference, the existence of a person or institution who dominates, who is able, at any moment, to interfere with our decision-making. It is not, she says, the character of the monarch, which is dangerous to liberty, but his very existence:

How can it be a virtue to love kings, be they good or bad, stupid or wise, good or evil doers, whether tyrants or the instruments of tyranny, sunk deep in indolence and abandoning the government to corrupt underlings! ${ }^{25}$

Monarchy is harmful, she says, even when it is benign: whether the king is stupid or evil, or wise and beneficent, it remains that those who live under his authority must crawl and be servile. ${ }^{26}$ In other words, a slave is a slave even when their master is kind. ${ }^{27}$ In what follows, I offer an analysis of what Grouchy regards as the costs of domination, which she seems to see as falling into two categories: moral and financial.

\subsection{The moral cost of domination}

Grouchy's depiction of the harms caused by monarchy is quite particular in that it relies on a psychological interpretation of the effects of domination. Like Kant, Grouchy sees the principle effect of being arbitrarily ruled as a sort of immaturity, an inability to judge for oneself what is right and what is just, a tendency to look to one's superior always and never to attempt to choose for oneself or do something one has not done before. ${ }^{28}$ Yet, her interpretation is significantly different. For Kant, immaturity is an intellectual failing - it is first and foremost the inability to form independent judgment. For Grouchy, it is also emotional: it is the inability to love one's liberty and the tendency to childishly attach to one's oppressor. In the Letters, she draws a precise picture of moral development as emotional development: one needs to learn to be attached to the well-being of others, first the physical well-being of those who are immediately close to us (the first morally significant relationship is that between a baby and her wet-nurse) and, ultimately, the moral and physical wellbeing of every member of the human race. Thus she is putting to work another concept that is regarded as central to republicanism: that of civic education. But for her, civic education begins at the cradle, and is not merely a question of imparting values but of developing the right kind of psychological habits. 
Grouchy's concern for the emotional development of the French and her observation that it is prevented by the domination of monarchy is apparent in the "Observations on the King's Letter":

Their respect [of the French for their King] is annihilated, as is their love: the heart of the French people, cured from this stupid and vain passion, has risen to the love of laws and country. Their soul, exalted by generous sentiments, will not go back to crawling at the feet of a prince. A king is the most infantile of rattles degrading the childhood of nations: the French no longer want rattles: they are grown. ${ }^{29}$

To be dominated for Grouchy is also to be emotionally stilted, infantile. To more mature Europeans, she says, the love of the French for their king was ridiculous, and even a sign of cowardice. But cowardice implies some failure to be courageous and a corresponding awareness that there was something wrong with loving a king, whereas in fact, the cause of this love was emotional immaturity, and the inability to develop real or lasting sentiments. Such sentiments would have made the French "friends of liberty" rather than lovers of the king. Their so-called love for their king is but a "stupid passion," and the king is nothing more to them than a childish amusement, something to stop them crying when they are hungry or bored. ${ }^{30}$ Thus Grouchy explains the central concept of republicanism, the absence of liberty that results from domination, in psychological terms, linking it to her later work on sympathy.

Indeed in Letter VII Grouchy tells us that social institutions privileging hereditary power are the cause of the domination of some by others, and that to get rid of them would result in everyone answering only to the law. ${ }^{31}$ Further, being dominated by another human being leads to a sense that the law does not matter, she says. Hence, those who live in a monarchy are more likely to be criminals: the very fact of being free to choose one's leaders by election would reduce the desire to act against the law. It is arbitrary power, again, which renders subjects morally stunted, incapable of right judgment or real loyalty. ${ }^{32}$ The gist of letter VII is that domination, even when it does not cause direct, visible harm, undermines the human capacity to develop into a moral being. This is observable not just among the poor-those might be said to be visibly harmed by monarchy, in so far as they are poor-but among the rich, the aristocrats, who instead of the desire to fulfill their charges as well as they can are motivated by vanity on the one hand and servility on the other-vanity because what moves them is an inflated and unjustified sense of their own worth, and servility as they owe their position to a king's good will, rather than to their own efforts.

\subsection{The financial cost of domination}

Another recurrent theme both in the "Letter from a young Mechanic" and the "Observations on the King's Letter" is the financial cost of maintaining a royal family. Grouchy, who had lived for some years in the Hotel de Monnaies while Condorcet was the inspector general of the Monnaie de Paris under Turgot, had some knowledge of economics. She may even have inherited certain theories regarding the free market from her husband. Condorcet himself advocated a liberal economy, attempting in 
1774 to solve the problem of the growing price of bread by letting the farmers decide how they sold their flour, instead of controlling the market. This led to the 'flour wars,' a confrontation between Turgot and Necker, and rioting Parisian bakers.

Given the importance that the price of bread and the conditions of life of the wheat farmers played at the beginning of the revolution, it is no surprise that economical considerations should have played a role in Condorcet's political arguments. This concern is also visible in both the texts I attribute to Grouchy. One of the main arguments in the short "Letter from a Young Mechanic" is that the cost in taxes for a mechanical royal family would represent a fraction of the cost of the actual king. The author estimates the cost of producing a court of two hundred machines, and the annual cost of maintaining the machines at half a denier per person. ${ }^{33}$ Moreover, as this king will not constitute a danger to liberty, there will also be a reduction in the moral cost.

The costliness of kings is a theme that is also very present in the "Observations on the King's Letter." In the first part of the text, the author observes that

King's palaces are out of proportion with human nature; the greats of nations fulfill the vilest offices for them; citizens vilify themselves in their presence and become mere subjects; our imagination turns them into gods to adore, and to whom we sacrifice human blood. For the brilliance of the throne, two hundred thousand men cut each other's throats. The crown's honour is the scourge of nations, and when kings talk of their glory, the earth is covered in mourning. ${ }^{34}$

In that passage, the cost is both moral (loss of status and dignity) and physical (loss of lives!). But there is also an economic element at play, a dire lack of efficiency in the way the kingdom uses its human resources: under a king, those that would serve the nation through their greatness become mere lackeys; and those that would provide the workforce kill each other.

By contrast, when she addresses the question of financial inequality in the Letters on Sympathy, Grouchy notes that even in order to sustain a 'natural' inequality of class, with one quarter of the income only divided equally between all citizens and the remaining three quarters divided randomly to allow for differences in wealth, a reasonably fertile country would yield sufficient income and property for all. There is more, therefore, to eighteenth-century France's predicament than an unequal distribution of wealth-that, of itself, need not spell injustice. What is unjust, and leads to further injustice, is the fact that distribution of income is decided not by law, but by men, and that it is done on a purely selfish basis. This in turn is the effect of unjust social institutions which

alone make it the case that it is man, and not the law that dominates man; that a great function is anything other than a difficult one to fill; that it offers personal rewards other than the honour of having fulfilled it well, or glory, if its nature allows the showcasing of great talents; that other titles are required for obtaining it than services rendered and public esteem; other means to gain it than to be perceived to be worthy of it. ${ }^{35}$ 
Corruption, not economic inequalities, is thus the cause of poverty, according to Grouchy. But at the same time, she does not condone the kind of inequality that is typical of the ancient regime, and that results in deep social inequalities. If the French are to achieve the sort of values needed for the flourishing of the nation, they must feel sympathy towards each other. They must recognize in each other a human being that is capable of suffering, and that responds in more or less the same way to the same stimulus. But the King of France, we saw in the "Letter from a Young Mechanic," is in fact little more to his people than a very expansive automaton: he is too distant, and his manner of living too alien to the majority of the French for them to be able to care what happens to him. If they do, it is in a religious, not a human way; they build him up as a deity and sacrifice themselves (and others) for him. This point is made very clearly in the Letters on Sympathy, where Grouchy argues that extreme inequality prevents us from seeing humanity in others. She gives the following example:

In order to recognize each other, virtues must be able to find each other, to be placed by fortune at the same height. The powerful man and the worker in his employ are too far away from each other to judge each other. And this distance causes their respective duties towards each other to be lost, one can oppress the other without remorse, and the other can in turn cheat him with impunity, even convincing himself that there is justice in the act. ${ }^{36}$

Thus, extreme inequality leads distant social classes no longer to regard each other as part of the same humanity. This is also, of course, the result of domination. The laws that dictate the practices sustaining this inequality are unjust laws, the purpose of which is to dominate and oppress. The ruling classes, no matter how benign they might be in some parts of the country, always have the power to render the life of those who work for them unlivable. The solution is then to destroy the institutions that permit such laws, and to replace them with just laws that do not aim to create extreme inequalities.

Indeed, Grouchy believes that very little positive intervention is required in order to make a nation just. "The rule of an ordinary conscience, together with reasonable laws will suffice to produce a just and good man." ${ }^{37}$ Of course, more work is needed to undo the injustice that royalist institutions brought about, but the positive part of her program for social justice relies in great part on the belief that we are not naturally prone to excessive greed and injustice, and that our desire for wealth will be served by a well-regulated free market.

Both the Letters on Sympathy, and the two articles I attribute to Grouchy point to the same arguments: domination is detrimental not only to freedom, but to the emotional and rational growth of citizens, their capacities to live together and rule themselves, and their economic well-being. This puts Grouchy (and possibly the other contributors of Le Républicain) well into the commercial republican tradition. Given the recent renewal of interest in the economic aspects of neorepublicanism, this means that focusing on Grouchy's work is very timely indeed. ${ }^{38}$ 


\section{NOTES}

1. Stephen Lukes and Nadia Urbanini, eds., Condorcet: Political Writings (Cambridge: Cambridge University Press, 2012).

2. Ibid., xxxiii-xxxiv.

3. Condorcet, Paine. Aux Origines de la République 1789-1792. Volume III Le Républicain par Condorcet et Thomas Paine, 1791 (Paris: EDHIS, 1991). All references to that publication are to the issue and page number of this text. All translations are my own.

4. In the 'Testament' he wrote for his daughter, Condorcet refers to the Letters, and to 'other writings' by her mother (Lukes and Urbinani, Condorcet: Political Writings, 204).

5. See Elisabeth and Robert Badinter, Condorcet (1743-1794) Un Intellectuel en Politique (Paris: Fayard, 1988), 217.

6. F.V.A. Aulard, Histoire Politique de la Révolution Française (Paris: Librairie Armand Colin, 1901), 440, footnote 2 .

7. “Avis aux Français," Le Républicain, 1:5.

8. Le Républicain, 1:8-9.

9. Ibid., $1: 9$ and $1: 14$.

10. For an English translation see Karin Brown and James McClellan III, "Letters on Sympathy (1798) A Critical Edition," Transactions of the American Philosophical Society, New Series, 98:4, (2008). For an annotated edition of the French text see Jean-Paul Lagrave, Sophie de Grouchy, Lettres sur la Sympathie suivies des Lettres d'Amour à Maillat Garat. (Montreal: Presses de l'Université du Québec, 1993), and for a critical edition see Marc-André Bernier and Deirdre Dawson, Les Lettres sur la Sympathies (1798) de Sophie de Grouchy: philosophie morale et réforme sociale (Oxford: Voltaire Foundation, 2010).

11. Dumont records in his memoirs having written this to both Clavière and Grouchy regarding his involvement and later retraction (Etienne Dumont, Souvenirs sur Mirabeau et sur les deux premieres Assemblées Législatives [Paris: Librairie de Charles Gosselin. 1832], 333). The original letters are lost.

12. For Grouchy's letters to Dumont see Jean Martin, Achille du Chastellet et le Premier Mouvement Républicain en France d'Après des Lettres Inedites (1791-1792) (Paris: L. Maretheux, Imprimeur de la Cour d'Appel, 1927), La Révolution Française (1931)34, 105-32. For tentative attributions of the "Letter" see Iain McLean, "The Paris Years of Thomas Jefferson," in A Companion to Jefferson, ed. Francis D. Cogliano (Wiley-Blackwell, 2011) 110-27; and Jean-Paul Lagrave, "L'influence de Sophie de Grouchy," in Condorcet: Mathématicien, économist, philosophe, homme politique, ed. Pierre Crépel (Paris: Colloque International, 1989), 437.

13. Condorcet's English was passable, but not up to a work of philosophical translation. Badinter and Badinter, Condorcet, 228. Dumont's involvement and refusal to translate the text is recorded in Dumont, Souvenirs sur Mirabeau, 321-22.

14. Even Robespierre did not consider himself a republican then: "The Jacobins, like the Assembly, go into convulsions whenever the Republic is mentioned" (Mme Roland, 1 July 1791, in Claude Perroud ed., Lettres de Madame Roland, [Paris: Imprimerie Nationale, 1900], 320-21).

15. Martin, Achille du Chastellet, 112.

16. Condorcet, "Fragments d'une justification (1793)" in A. Condorcet O'Connor and M.F. Arago, Oeuvres I (Paris: Firmin Didot Freres, Libraires, 1849), 609.

17. Ibid., "Eloge de Vaucausson," 413-37.

18. Le Patriote Francais, 9 July 1791.

19. Bernier and Dawson, Les Lettres sur la Sympathies, 91.

20. See for instance Mary Wollstonecraft, $A$ Vindication of the Rights of Woman (Oxford: Oxford University Press,1792/1995), 133, and Claudia Johnson, Equivocal Beings (Chicago: University of Chicago Press, 1995).

21. Dumont, Souvenirs sur Mirabeau, 333, my translation. The "Observations on the King's Letter" was in fact published in issues 2 and 3 , but it is the only piece published over two issues.

22. Le Républicain 2: 20-21.

23. See Letter IV, 57, for Grouchy's stated disagreement with Smith. All translations from the Letters on Sympathy are my own: Page references to the Letters refer back to the French text in the Bernier and Dawson edition.

24. Le Républicain 3, 37.

25. Ibid., 2:20.

26. Ibid., 2:21. 
27. See Philip Pettit, Republicanism (Oxford: Oxford University Press, 1997) 22ff, 272.

28. Immanuel Kant, “An Answer to the Question: 'What is Enlightenment?” in Kant: Political Writings, ed. Reiss, Cambridge: Cambridge University Press, 1991), 54-60, 54, 55.

29. Le Républicain, 2:21.

30. Ibid., 2.22.

31. Bernier and Dawson, Les Lettres sur la Sympathies, 90.

32. Ibid., 91.

33. A halfpenny-contrast to five shillings for a pound loaf of bread.

34. Le Républicain, 2:27.

35. Bernier and Dawson, Les Lettres sur la Sympathies, 88.

36. Ibid., 101.

37. Ibid., 95.

38. Richard Dagger, "Neo-Republicanism and the Civic Economy," Philosophy, Politics, Economics 5(2) (2006),151-73; Philip Pettit, "Freedom in the Market," in the same volume, 131-49. Thanks to Karen Green, Ruth Hagengruber, and Jim McClellan for their comments and encouragement; also to Bill Wringe, Alp Rodoplu, Eric Schliesser, Philip Pettit, and Alan Coffee for their comments on earlier versions. Thanks especially to Evrim Emir Sayers for finding a copy of Le Républicain and sending it to me, and to Madeleine Arnold-Tetard, whose work on Grouchy's life inspired me to look for other texts she may have written. 